\title{
STRATEGI PENGEMBANGAN BISNIS PUPUK RUMAH KOMPOS UIN JAKARTA
}

\author{
Elpawati*, Muhammad Herlambang**, Ahmad Mahbubi***
}

\begin{abstract}
ABSTRAK
Tujuan dari dilakukanya penelitian ini adalah: Mengetahui Faktor-faktor Internal dan Eksternal yang menjadi Kekuatan, Kelemahan, Peluang dan Ancaman bagi Rumah Kompos UIN Jakarta. Mengetahui posisi Rumah Kompos UIN Jakarta berdasarkan Matrik IE dan sembilan sel strategi. Merumuskan Alternatif Strategi Pengembangan bisnis yang tepat untuk diterapkan pada Rumah Kompos UIN Jakarta. Metode dan analisis yang digunakan dalam penelitian ini dibagi menjadi tiga tahapan, yaitu: Tahapan masukkan (Input Stage) yang terdiri dari Matrik EFE (External Factor Evaluation) dan Matrik IFE (Internal Factor Evaluation). Tahap pencocokan (Matching Stage) yang menggabungkan faktor eksternal dan internal perusahaan, yang terdiri dari Matriks SWOT (Strengths, Weaknesses, Opportunities, Threats) dan Matrik IE (Internal, External). Tahapan penentuan prioritas strategi perusahaan (Decision Stage) berdasarkan jumlah alternative strategi dengan menggunakan metode QSPM (Quantitative Strategic Planing Matrix). Berdasarkan hasil perhitungan matriks IFE Kekuatan utamanya adalah visi-misi dan lokasi perusahaan yang dimiliki Rumah Kompos, total nilai 0.40. Sedangkan hasil perhitungan matriks EFE Peluang sangat berpengaruh terhadap pengembangan Rumah Kompos adalah kebijakan pemerintah program Go Organik 2010 dengan total nilai 0.30. Ancaman yang berpengaruh pada rumah kompos adalah perubahan cuaca dan iklim dengan total nilai 0.44. Hasil Matriks QSPM Prioritas utama yang dapat dijalankan Rumah Kompos adalah: (1) Peningkatan Kualitas Dan Kapasitas Produksi dengan total skor 6.986 (2) Pengembangan Pasar dengan skor 6.913 (3) Kerjasama Dengan Mitra Dan Pemasok dengan skor 6.020 (4) Merekrut Tenaga Kerja Baru dengan skor 5.293 (5) Memperbaiki Sistem Manajemen Guna Menahan Persaingan Luar dengan skor 4.893 (6) Menata Ulang Struktur Organisasi, Pembagian Tugas Sesuai Dengan Sop dengan skor 4.740.
\end{abstract}

Kata Kunci : SWOT, Matik EFE, Rumah Kompos UIN, QPSM, Matrik IE,

\begin{abstract}
The purpose of this study is to determine the internal and external factors that become strengths, weaknesses, opportunities and threats for UIN Jakarta compost home and to determine the position of UIN Jakarta compost home based on matrix IE and nine cell strategies and to formulate alternative appropriate business development strategies to be applied in the UIN Jakarta compost home. Methods and analysis used in this study are
\end{abstract}


divided into three stages, namely: input stage consisting of matrix EFE (External Factor Evaluation) and Matrix IFE (Internal Factor Evaluation). Matching Stage which combines external and internal factors of the company consists of Matrix SWOT (Strengths, Weaknesses, Opportunities, Threats) analysis and IE Matrix (Internal, External). Stages prioritization strategy of the company (Decision Stage) based on the number of alternative strategies using QSPM (Quantitative Strategic Planing Matrix). Based on the results of IFE matrix calculations, the principal strength is vision, mission and company-owned locations in the compost home with the total value of 0.40. While the results of EFE matrix calculations, the opportunity is the government policy program Go Organic 2010 with a total value of 0.30. Threats that affect compost home is a change in weather and climate for a total value of 0.44. Results of Matrix QSPM show that the main priorities which can be adapted by compost home are: (1) improving the quality and the production capacity with a total score of 6.986, (2) developing market development with a score of 6.913, (3) collaborating with partners and suppliers with a score of 6.020, (4) hiring new labors with a score of 5.293 (5) improving the management system to withstand external competition with a score of 4.893 (6) reorganizing organizational structure, division of tasks in accordance with standard operational prosedure (SOP) with a score of 4.740 .

Keyword : SWOT, Matic EFE, Home Compost UIN, QPSM, Matric IE,

\section{PENDAHULUAN}

Sampah masih merupakan salah satu masalah yang serius di ibu kota Jakarta dikarenakan volume sampah yang semakin meningkat jumlahnya setiap hari dan tidak dapat tertangani seluruhnya oleh Dinas Kebersihan setempat. Jika sekilas kita melihat data tentang sampah di ibukota Negara Indonesia DKI Jakarta yang setiap tahunnya bertambah sekitar $1000 \mathrm{~m}^{3}$. Hal tersebut disebabkan oleh pertama, banyaknya orang yang tinggal atau kerja di Jakarta membuat tingkat volume sampah yang dihasilkan sebanding dengan jumlah penduduknya. Kedua, semakin tinggi kesejahteraan suatu masyarakat,maka gaya hidup akan semakin praktis dan instan,serta konsumtif. Tingkat ekonomi semakin tinggi tentu berhubungan dengan tingkat konsumsi yang tinggi,yang pada akhirnya akan menghasilkan sampah lebih banyak.
Volume sampah DKI Jakarta per hari sekitar 6.500 ton atau $28.000 \mathrm{~m}^{3}$ yang terdiri dari 53\% sampah rumah tangga dan $47 \%$ sampah industri, belum lagi bila ditambah dengan sampah yang berasal dari kotakota sekitarnya. (Sa'diyah,2013:1) Sampah yang ada di Jakarta juga berasal dari kota-kota penyangga disekitarnya seperti Tangerang, Bekasi, Depok, Bogor dan lainnya. Tangerang Selatan merupakan salah satu daerah tetangga dan penyangga Jakarta dan merupakan salah satu kota penyumbang sampah yang ada di Jakarta. Kota yang resmi berdiri pada 26 November 2008 ini, memiliki penduduk sebanyak 1,3 juta jiwa. Kota Tangerang Selatan menghasilkan sampah sekitar $1600 \mathrm{~m}^{3}$ per hari.

Tiap satu hari, sekitar 0,56 kilogram sampah dihasilkan oleh satu warga. Karena itu, penduduk Tangerang Selatan 
menghasilkan sampah sebanyak 728.000 kilogram tiap harinya (Reza,2013:1). Hal ini membuat kota Tangerang Selatan sebagai salah satu contoh kota yang tidak dapat menanggulangi sampah yang ada. Dapat terlihat tumpukan-tumpukan sampah yang menggunung di beberapa titik jalan maupun pasar yang ada di Tangerang Selatan.

Dampak masalah sampah ini sebenarnya berakibat untuk seluruh lapisan masyarakat. Bagi kalangan menengah ke atas, kawasan komersil, dan kawasan industri, permasalahan tersebut memberi dampak yang signifikan bagi kenyamanan maupun perkembangan bisnis. Sedangkan untuk kalangan menengah ke bawah sampah dapat mengakibatkan gangguan kesehatan dan penyakit. Upaya yang telah dilakukan Dinas Kebersihan Tangerang Selatan memang masih relatif kecil yaitu baru menambah jumlah bak-bak sampah di tempat pengumpulan sampah tanpa diimbangi dengan penambahan jumlah personil maupun armada untuk menangani sampah.

Melihat peluang dan atas keprihatinan dengan keadaan tersebut, Rumah Kompos UIN Jakarta turut berpartisipasi dalam penanggulangan sampah yang ada khususnya dilingkungan UIN sendiri yang secra administasi berada di wilayah Tangerang Selatan. Penerapan manajemen sampah yang baik, maka permasalahan sampah dapat diselesaikan dan memberi nilai ekonomis bagi pengelolanya.

Pendapatan dapat diperoleh dari retribusi sampah dan dari hasil olahan sampah yang bernilai ekonomis seperti kompos, pupuk cair, plastik dan kertas.
Rumah Kompos UIN Jakarta memiliki dua produk unggulan dari hasil pengolahan sampah yang ada di sekitarnya yaitu pupuk kompos dan pupuk cair EM10. Kedua produk olahan dari sampah dan bahan organik tersebut mempunyai manfaat masing-masing, khususnya manfaat di bidang pertanian.

Melihat besarnya potensi dan manfaat Rumah Kompos UIN Jakarta, maka peneliti melakukan penelitian dengan judul " Strategi Pengembangan Bisnis Pupuk Rumah Kompos UIN Jakarta". Untuk melihat sejauh mana Rumah Kompos sudah berkontribusi dalam penanganan sampah khususnya dilingkungan UIN Jakarta sendiri dan sudah sejauh mana produk Rumah Kompos UIN Jakarta dikenal di masyarakat, serta melihat keadaan posisi Rumah Kompos pada fase hidup perusahaan.

Seiring dengan berjalannya waktu minat masyarakat terhadap Produk Rumah Kompos UIN Jakarta pun semakin meningkat sehingga diperlukan langkahlangkah strategis yang harus diambil dalam rangka pengembangan bisnis dan keberlanjutan usaha dari Rumah Kompos UIN Jakarta.

Untuk itulah hal yang perlu dianalisis antara lain: (1) Apa saja Faktorfaktor Internal dan Eksternal yang menjadi Kekuatan, Kelemahan, Peluang dan Ancaman bagi Rumah Kompos UIN Jakarta? (2) Dimana posisi Rumah Kompos UIN Jakarta berdasarkan Matrik IE dan sembilan sel strategi? (2) Bagaimana Alternatif Strategi Pengembangan bisnis yang tepat untuk diterapkan pada Rumah Kompos UIN Jakarta? 


\section{METODE PENELITIAN}

Metode penelitian ini menggunakan tipe riset konklusif yang bertujuan untuk memberikan masukan dalam mengambil keputusan, mengevaluasi dan memilih alternatif terbaik dalam memecahkan suatu masalah. Metode yang digunakan adalah analisis deskriptif dengan menggunakan analsis tiga tahap formulasi strategi dengan bantuan Matriks IFE, EFE, IE, Matriks SWOT dan QSPM. (Rangkuti, 2006:16).

Penelitian ini dilaksanakan di Rumah Kompos UIN Jakarta yang beralamat di Jalan Asrama Putra, Komplek Perumahan Dosen UIN Syarif Hidyatullah Jakarta, Kecamatan Ciputat Timur, Kabupaten Tangerang Selatan. Penentuan lokasi dilakukan secara sengaja (Purposive) dikarenakan subjek penelitian merupakan direksi, manajer dan staff rumah kompos UIN Jakarta.

Penelitian ini dilakukan pada bulan Juli sampai dengan bulan September tahun 2013. Data yang digunakan dalam penelitian ini meliputi data primer dan data sekunder. Data primer dikumpulkan melalui informasi dan pengamatan langsung di lapangan terhadap kegiatan usaha dan hasil wawancara dengan narasumber/pakar.

Data sekunder diperoleh melalui literatur ataupun studi pustaka yang mendukung penelitian. Data tersebut dapat bersumber dari data laporan internal perusahaan, surat kabar, situs-situs internet, Badan Pusat Statistik (BPS), buku teks manajemem strategis, hasil penelitian, dan data-data dari beberapa instansi terkait lainnya.

\section{METODE ANALISIS DATA}

Metode Analisis data yang diperoleh dianalisis menggunakan metode kualitatif berdasarkan analisis deskriptif dan konsep-konsep manajemen strategis yang ada, sehingga mampu memberikan gambaran dan penjelasan mengenai masalah yang terjadi. Selanjutnya, menganalisis data kuantitatif dengan menggunakan metode analisis tiga tahap formulasi strategi. Analisis deskriptif bertujuan untuk mendefinisikan visi, misi dan tujuan perusahaan, karakteristik produk yang dihasilkan, tingkat pencapaian target penjualan, kegiatan pemasaran, personalia, produksi/operasi, penelitian dan pengembangan serta informasi yang digunakan perusahaaan.

Analisis ini bertujuan untuk menggambarkan kondisi riil perusahaan. Proses perumusan strategi didasarkan pada kerangka tiga tahap formulasi strategi yang terdiri dari pertama tahap masukan (input), kedua tahap pencocokan dan ketiga tahap keputusan. Analisis tiga tahap formulasi strategi yang digunakan dalam penelitian ini meliputi: (1) Analisis lingkungan eksternal dan internal. Matriks Internal Factor Evaluation (IFE) dan Matriks Eksternal Factor Evaluation (EFE), (2) Analisis Matriks Internal-External (IE), analisis Matriks Strength-WeaknessOpportunities-Threats (SWOT), Analisis Quantitative Strategic Planning Matrix (QSPM).

\section{HASIL DAN PEMBAHASAN}

Analisis lingkungan internal dan eksternal dilakukan untuk mengetahui faktor-faktor strategis yang berpengaruh terhadap keberadaan dan kegiatan 
pengembangan bisnis Rumah Kompos UIN Jakarta antara lain kekuatan, kelemahan, peluang, dan ancaman. Lingkungan internal merupakan faktor-faktor yang mempengaruhi perusahaan yang datangnya dari dalam perusahaan sendiri. Faktorfaktor di dalam Rumah Kompos yang menjadi kekuatan dan kelemahan dan kegiatannya dikendalikan oleh perusahaan itu sendiri. Kegiatan tersebut terdiri dari penerapan manjemen, produksi, pemasaran, keuangan. Sedangkan lingkungan eksternal merupakan lingkungan yang ada di luar perusahaan yang menjadi peluang dan ancaman dan kegiatannya tidak dapat dikendalikan oleh

\section{Rumah Kompos. Lingkungan} eksternal terdiri dari lingkungan mikro dan makro. Lingkungan makro antara lain politik, sosial, budaya, demografi, lingkungan, ekonomi, pemerintah, hukum, teknologi, dan kompetitor.

\section{Manajemen}

Manajemen merupakan sebuah sistem yang terdiri dari perencanaan, pengorganisasian, kepemimpinan, dan pengendalian. Manajemen suatu tim maupun organisasi diarahkan untuk mendukung segala kegiatan yang berlangsung guna mencapai tujuannya. Kegiatan perencanaan yang dilakukan di Rumah Kompos berupa menyusun konsep produk, harga, penanganan bahan baku, dan pemasaran.

Kegiatan pengorganisasian yang dilakukan di Rumah Kompos berupa membuat struktur organisasi, membuat tugas kerja yang akan di jalankan dari setiap SDM, menunjuk atau memilih siapa yang akan menjalankan tugas tersebut, dan bagaimana cara melakukan pekerjaan tersebut. Hal ini dilakukan agar setiap SDM di Rumah Kompos menjalankan pekerjaan berdasarkan tugasnya masingmasing sehingga menjadi teratur.

Kegiatan kepemimpinan di rumah kompos dipimpin langsung oleh pencetus ide yaitu Dr. Elpawati, tetapi dalam pengambilan keputusan dimusyawarahkan bersama pengurus yang ada baik pada manajemen puncak maupun manajemen bawah. Dr. Elpawati dalam menjalankan tugasnya sebagai pimpinan dapat memberikan motivasi kepada bawahannya dan mampu mempengaruhi bawahannya, sehingga setiap bawahannya bisa terus bersemangat dalam menjalankan pekerjaannya, bahkan beliaupun tidak sungkan untuk terjun langsung pada bagian produksi.

Kegiatan pengendalian di rumah kompos dilakukan untuk memantau apakah kegiatan yang telah dijalankan sudah berjalan sesuai dengan rencana atau belum, jika tidak berjalan sesuai dengan rencana maka perlu adanya tindakan korektif. Hal ini dilakukan untuk mengevaluasi dari setiap kegiatan, agar pada saat menjalankan kegiatan yang selanjutnya tidak lagi terulang kesalahan yang sama. Kegiatan manajemen yang dilakukan rumah kompos masih sederhana hal ini dapat dilihat dari struktur organisasi yang ada, disini baru tersusun organisasi yang terdiri penasehat, ketua, wakil, sekertaris, div. Bahan Baku, div. Produksi.

Rumah Kompos dikelola oleh tenaga-tenaga dari kalangan UIN sendiri baik melibatkan dosen, mahasiswa maupun karyawan. Sumber daya rumah kompos masih amat minim, rumah kompos baru mempunyai sumber daya sekitar 6 orang 
yang terdiri dari 4 orang pada manjemen puncak dan 2 orang sebagai tenaga operasional. Oleh karena itu kegiatan operasional pada rumah kompos belum bisa optimal.

\section{Pemasaran}

Produk utama yang dihasilkan oleh Rumah Kompos adalah pupuk kompos yang diperoleh dari hasil produksi sendiri. Akan tetapi pada saat ini Rumah Kompos mengembangkan varian produk berupa pupuk organik cair EM10 yang mempunyai fungsi sebagai pengurai sampah dan bisa juga digunakan untuk pupuk tanaman. Promosi yang dilakukan rumah kompos melalui beberapa cara antara lain (1) iklan berupa brosur, spanduk, papan. (2) pameran di event agribisnis, pameran di pasar kaget mingguan. (3) stand harian di rumah kompos.

\section{Keuangan}

Sumber modal rumah kompos merupakan bantuan dan kerja sama dari beberapa instansi antara lain BRI, LIPI,dan UIN sendiri. Modal yang didapat dari pengajuan proposal tersebutlah yang menjadi sumber dana pengurus rumah kompos untuk membuat pabrik kompos dan menyiapkan segala fasilitasnya. Kegiatan pemantauan, pencatatan dan pengendalian keuangan dilakukan oleh sekertaris yang hasilnya kemudian dilaporkan lagi kepada ketua.

Sistem pencatatan laporan keuangan di rumah kompos masihlah sederhana dan belum tersistematis, oleh karena itu terkadang terjadi kesalahan maupun kekurangan data pada pencatatan keuangan.

\section{Analisis Lingkungan Eksternal}

\section{Ekonomi}

Kondisi perekonomian negara yang tidak stabil menjadi ancaman bagi rumah kompos. Hal ini mengakibatkan berkurangnya daya pembelian pupuk kompos dan pada akhirnya akan berpengaruh pada pendapatan dan pengembangan rumah kompos. Dengen naiknya harga-harga kebutuhan pokok tersebut, maka masyarakat akan lebih selektif lagi dalam membeli sesuatu. Selain itu, kenaikan harga BBM pada tahun 2013 dapat memberikan pengaruh negatif karena secara tidak langsung akan mempengaruhi naiknya harga-harga kebutuhan dan dapat meningkatkan biaya operasional yang harus dikeluarkan oleh rumah kompos.

\section{Sosial dan Budaya}

Pertumbuhan dan perkembangan pembangunan yang cukup pesat saat ini, membuat gaya hidup masyarakat yang semakin modern dan jauh dari kesan alami. Akan tetapi saat ini sudah banyak cara pandang masyarakat yang sudah mulai sadar akan pentingnya kesehatan dan mulai kembali ke alam atau organik. Mulai dari bahan makanan maupun produk-produk lain yang berbau organik. Dalam proses pertumbuhan tanaman, masyarakat umum maupun petani sudah mengurangi penggunaan pupuk kimia/anorganik karena mereka sudah mengerti akan dampak dari pemakaiannya.

Masyarakat sekarang sudah mulai gemar menggunakan pupuk organik atau pupuk yang berasal dari bahan-bahan organik seperti pupuk kompos, pupuk hayati, maupun pupuk organik cair. Hal ini 
berdampak positif bagi rumah kompos karena daya beli masyarakat terhadap pupuk kompos yang semakin meningkat.

\section{A. Politik}

Dengan dicanangkannya GO ORGANIK 2010 oleh pemerintah, pemahaman masyarakat tentang produk organik semakin meningkat, dan oleh sebab itu maka mulai berkembangnya seluruh industri di sektor pertanian. Salah satunya adalah para pelaku industri Pupuk Organik. Para pelaku pupuk organik bukan hanya berskala besar, tetapi juga skala rumah tangga. Dengan memanfaatkan limbah dan bahan organik di lingkungan maka akan menghasilkan nilai tambah ekonomis dan sosial budaya. Hal inilah yang dimanfaat rumah kompos untuk ikut berpartisipasi dalam pelaksanaan program pemerintah.

\section{B. Teknologi}

Perkembangan teknologi sangat mempengaruhi produksi rumah kompos UIN Jakarta, semakin tinggi teknologi yang digunakan dalam aspek produksi semakin bervariasi metode dalam pembuatan pupuk kompos dan semakin efektif serta efisien kegiatan produksi. Rumah Kompos mengembangkan produknya dengan menghasilkan produk baru yaitu EM10. Sedangkan pada aspek pemasaran perkembangan teknologi sangatlah membantu dalam promosi maupun hubungan dengan pelanggan.

\section{Analisis kekuatan, kelemahan, peluang, serta ancaman Rumah Kompos}

Tahap Input Stage dimulai dengan identifikasi lingkungan internal perusahan untuk menentukan faktor-faktor kekuatan dan kelemahan. Berdasarkan hasil wawancara tahap pertama dengan narasumber, didapatkan bahwa yang menjadi kekuatan dan kelemahan dijelaskan pada Tabel 1.

\section{Faktor Internal}

Dari hasil identifikasi faktor internal didapatkan beberapa hal yang menjadi kekuatan serta kelemahan perusahaan. Faktor-faktor kunci tersebut, adalah:

\section{Kekuatan}

a) Visi dan Misi Perusahaan

Rumah kompos saat ini sudah memiliki visi dan misi walaupun pada awal didirikannya rumah kompos belum memiliki visi dan misi secara tertulis, baru sekitar tahun 2012 perusahaan membuatnya.

Visi rumah kompos antara lain :

1) Menjadi Pusat Riset dan Penelitian bagi Dosen, Mahasiswa UIN Jakarta, Maupun Masyarakat Umum dalam hal Pupuk Organik.

2) Menjadi Produsen Kompos dan Micro Organisme penghancur sampah Organik yang memiliki daya saing secara Nasional 
Tabel 48. Hasil Penentuan Faktor-Faktor Strategis Internal

\begin{tabular}{|c|c|}
\hline \multicolumn{2}{|c|}{ Faktor-Faktor Strategis Internal } \\
\hline Kekuatan & Kelemahan \\
\hline 1. Visi dan Misi Perusahaan & 1. Ketersediaan Sumber daya Manusia \\
\hline 2. Kualitas Produk & 2. Spesifikasi Pekerjaan Tiap Sumber daya \\
\hline 3. Harga Produk & Manusia \\
\hline 4. Lokasi Perusahaan & 3. Pembukuan Keuangan \\
\hline 5. Fasilitas Produksi dan & 4. Pemasaran Produk \\
\hline Operasi & 5. Kapasitas Produksi \\
\hline 6. Lahan yang Luas & \\
\hline 7. Bahan Baku yang & \\
\hline Melimpah & \\
\hline
\end{tabular}

(Sumber : Lampiran 4)

Misi :

1) Memanfaatkan sampah-sampah yang selama ini dianggap tidak berguna menjadi barang yang memiliki manfaat serta melestarikan lingkungan.

2) Menghasilkan suatu produk yang dapat dijual dan dapat meningkatkan pendapatan.

3) Mengembangkan hasil riset inovatif yang memiliki nilai tambah ilmiah, ekonomi dan sosial serta berwawasan lingkungan.

\section{b) Kualitas Produk}

Produk pupuk kompos dan pupuk cair yang diproduksi Rumah Kompos telah diuji melalui tes di laboratorium. Bahan baku yang digunakan untuk memproduksi pupuk kompos terdiri dari 2 jenis, yaitu bahan baku utama dan bahan baku pendukung. Bahan baku utama yaitu sampah organik yang berupa dedaunan dan rumput.
Sedangkan bahan baku pendukung antara lain kotoran sapi, sekam bakar, dan EM 10. Penggunaan bahan baku pada setiap proses produksi diatur sesuai takaran yang telah ditetapkan. Untuk sampah organik yang digunakan dalam satu kali proses produksi sebesar 50\%, kotoran sapi $40 \%$, dan sekam bakar sebesar 10\%. Setelah itu ditambah EM10 (Effective Mikroorganisme 10) yang berfungsi untuk mempercepat proses fermentasi pada pembuatan kompos.

Pupuk kompos UIN Jakarta telah memenuhi standar minimum dari SNI pupuk kompos, dengan jumlah unsur $\mathrm{N}=$ $4,67 \%, \mathrm{P}=2,92 \%$, dan $\mathrm{K}=5,13 \%$. EM 10 merupakan pupuk organik cair yang berbahan baku molases. Molases adalah limbah industri gula yang dapat dimanfaatkan. Molases tebu kaya akan biotin, asam pantotenat, tiamin, fosfor, dan sulfur. Sedikit mengandung nitrogen organik.

Mengandung $62 \%$ gula yang terdiri dari sukrosa $32 \%$, glukosa $14 \%$, dan fruktosa $16 \%$. Selain molase EM 10 Isolat bakteri juga terdapat di dalam EM10 yang 
merupakan hasil isolasi dari sampah di daerah Kampung Utan. Diperoleh delapan isolat bakteri yang terbaik hasil degradasi pada penelitian sebelumnya. Delapan isolat bakteri ini adalah yang paling tinggi kualitasnya dalam menghancurkan sampah organik karena persentasi degradasinya lebih besar daripada bakteri lainnya. Delapan isolat bakteri ini diberi nomor 11 , $22,15,21,30,6,1$, dan 31 .

Produksi EM 10 juga ditambah 3 isolat berupa yeast (Saccharomyces cerevisiae), kapang (Trichoderma dan Penicillium). Dari hasil pengujian N, P, K (Tabel.1 ) menunjukkan bahwa kandungan P pupuk EM 10 sudah memenuhi standar mutu pupuk cair organik

\section{c) Harga Produk}

Rumah kompos mempunyai 2 produk unggulan yakni pupuk kompos dan pupuk cair EM 10 yang masing-masing produk memiliki variasi kemasan yang berbeda. Untuk pupuk kompos terdapat 3 variasi ukuran yaitu berat $1 \mathrm{~kg}$ dengan harga Rp. 3000, 4kg seharga Rp. 10.000, dan 15kg Rp. 30.000. sedangkan untuk pupuk cair EM10 terdapat 2 variasi ukuran yaitu $250 \mathrm{ml}$ dengan harga Rp. 7500 dan 1L seharga Rp. 15.000 .

Dari harga yang ditawarkan tersebut rumah kompos sebenarnya mampu bersaing dengan perusahaan sejenis. Bahkan terkadang ditemukan bahwa harga yang ditawarkan rumah kompos masih lebih murah dibanding kompetitor.

d) Lokasi Perusahaan
Rumah Kompos UIN Jakarta terletak di Jalan Asrama Putra Komplek Perumahan Dosen UIN Syarif Hidayatullah Jakarta, Kecamatan Ciputat Timur, Kabupaten Tangerang Selatan. Dari sisi produksi hal ini sangat menguntukan karena suplay bahan baku yang berasal dari kampus 1 dan kampus 2 relatif dekat dengan lokasi sehingga bisa mengefesiensikan biaya transportasi.

Begitupun dari sisi pemasaran hal ini sangat mempermudah rumah kompos untuk medistribusikan produk dan hal ini dapat memotong jarak distribusi karena target pasar dari rumah kompos itu sediri pada jangka waktu dekat ini adalah warga komplek sekitar pada khususnya dan seluruh masyarakat Tanggerang Selatan pada umumnya.

\section{e) Fasilitas Produksi dan Operasi}

Fasilitas produksi dan operasi pada rumah kompos sudah cukup lengkap, pada aspek produksi alat-alat maupun mesinmesin yang dibutuhkan untuk operasional produksi sudah ada antara lain yang telah di rincikan pada Tabel 9 dan Tabel 10. Akan tetapi karena perawatan yang kurang dan sudah termakan waktu banyak terdapat alat-alat yang rusak dan hilang begitupun dengan mesin terdapat beberapa yang rusak dan sering macet yang dapat mempengaruhi aktivitas produksi.

f) Lahan yang Luas

Luas lahan Rumah Kompos yaitu $500 \mathrm{~m}^{2}$. Luas dari bangunan yang ada yaitu $6 \mathrm{~m} \mathrm{X} 12 \mathrm{~m}$ yang terdiri dari; ruang produksi untuk mencacah, mengayak, menghaluskan dan menyimpan pupuk yang di fermentasikan. Kemudian Gudang 
persediaan, ruang kantor, kamar mandi, parkir kendaraan.

Sebanarnya baru sekitar 1/5 lahan pada rumah kompos yang dipergunakan, sebagian digunakan untuk tempat praktikum maupun uji coba dan sisanya masih berupa rerumputan. Oleh karenaya masih terdapat banyak lahan kosong yang masih dapat dipergunakan baik untuk memperluas areal produksi maupun membuat bangunan baru baik itu laboratorium maupun tempat tinggal pegawai.

g) Bahan Baku yang Melimpah

Bahan baku pupuk kompos terdiri dari beberapa yaitu bahan baku utama dan bahan baku pendukung. Bahan baku utama merupakan sampah dedaun atau rerumputan sedangkan bahan baku pendukung berupa kotoran sapi, sekam, EM 10. Bahan utama yang merupakan komposisi utama sekitar $50 \%$ berasal dari kampus 1,2 dan 3 UIN Jakarta karena masih banyak terdapat pepohonan yang setiap hari menghasilkan sampah dedauanan.

Sedangakan bahan pelengkap lain berupa kotoran sapi didatangkan dari daerah Tapos Depok yang dibeli seharga Rp. 800/kg, dan sekam bakar didatangkan dari Sukabumi yang dibeli dengan harga Rp. 8000/karung, sedangakn untuk EM 10 rumah kompos sudah dapat membuatnya sendiri.

\section{Kelemahan}

a) Ketersediaan Sumber daya Manusia

Rumah Kompos UIN Jakarta memiliki sumber daya manusia yang terbatas, hal ini dapat dilihat pada struktur organisasi yang ada, padahal sebenarnya untuk operasional baik itu produksi sampai pada pemasaran produk membutuhkan orang yang relatif banyak. Pada saat ini rumah kompos hanya mempunyai seorang petugas operasional yaitu Alias Biantara sedangkan Julian

Sono sudah tidak bekerja lagi dan sampai sekarang belum ada penggantinya. Pada saat ini kegiatan operasioanal rumah kompos hanya bertumpu kepada sekertaris Yelvi Erida yang terjun langsung memantau dan membantu proses aktivitas produksi maupun pemasaran dan juga dibantu mahasiswa-mahasiswi yang sedang penelitian dan praktik kerja lapang.

b) Spesifikasi Pekerjaan Tiap Sumber daya Manusia

Sumber daya manusia pada Rumah Kompos sangat terbatas, hal ini sangat mempengaruhi kinerja masingmasing jabatan sehingga belum terealisasinya spesifikasi pekerjaan tiap sumber daya manusia secara baik. Untuk saat ini setiap tanggung jawab pekerjaan masih dipegang rangkap oleh beberapa sumber daya yang masih ada.

c) Pembukuan Keuangan

Rumah Kompos masih menggunakan sistem pembukuan pencatatan keuangan yang sederhana karena menyadari keterbatasan sumber daya manusianya dan belum terealisasinya spesifikasi pekerjaan secara merata pada setiap sumber daya manusia. Dilihat dari laporan 
administrasi perusahaan, perusahaan tidak melakukan pencatatan laporan laba rugi dan neraca keuangan perusahaan, dalam beberapa tahun terakhir. Dan akibat dari kurang tertibnya administrasi keuangan terkadang ditemukan transaksi yang tidak dimasukkan.

d) Pemasaran Produk

Kegiatan pemasaran yang dilakukan Rumah Kompos masih sangat terbatas, pemasaran yang telah dilakukan antara lain pada pameran agribisnis, stand di pasar kaget mingguan, stand harian di halaman Rumah Kompos, kemitraan dengan toko pertanian sekitar Tangerang Selatan, dan kemitraan dengan organisasi kampus yang memerlukan pupuk kompos untuk kegiatannya.

e) Kapasitas Produksi

Rumah Kompos sebenarnya sudah cukup mumpuni yaitu sudah bisa memproduksi pupuk kompos sekitar 5 Ton per bulan, akan tetapi pada pelaksanaanya banyak hal yang mempengaruhi baik itu dari supply bahan baku yang berkurang maupun rusaknya beberapa mesin yang sering macet dan terdapat yang rusak. Pada saat ini rumah kompos hanya sering melayani pesanan pupuk kompos sedangkan untuk stok masih sangat terbatas jumlahnya. Hal ini yang mempengaruhi rumah kompos belum bisa memasarkan produknya secara berkelanjutan.

\section{Faktor Eksternal}

Tahap Input Stage dimulai dengan identifikasi lingkungan eksternal perusahaan untuk menentukan faktor-faktor peluang, dan ancaman. Berdasarkan hasil wawancara tahap pertama dengan narasumber, didapatkan bahwa yamg menjadi peluang dan ancaman antara lain dijelaskan pada Tabel 2.

Tabel 49. Hasil Penentuan Faktor-Faktor Strategis Eksternal

\begin{tabular}{|c|c|}
\hline \multicolumn{2}{|c|}{ Faktor-Faktor Strategis Eksternal } \\
\hline Peluang & Ancaman \\
\hline 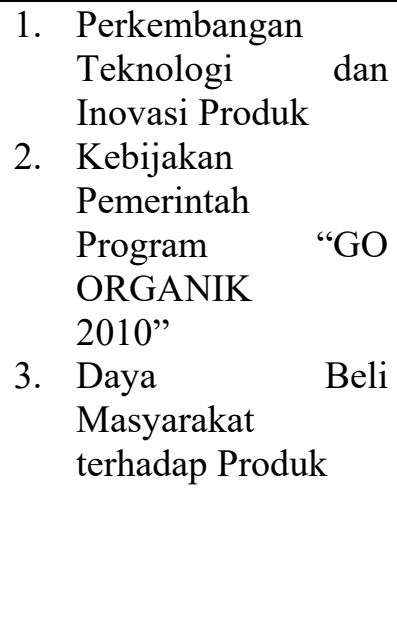 & $\begin{array}{l}\text { 1. Kenaikan } \\
\text { TDL dan } \\
\text { Kenaikan } \\
\text { BBM } \\
\text { 2. Persaingan } \\
\text { Harga Produk } \\
\text { 3. Kenaikan } \\
\text { Harga Bahan } \\
\text { Baku } \\
\text { 4. Produk } \\
\text { Subtitusi } \\
\text { 5. Perubahan } \\
\text { Cuaca dan } \\
\text { Iklim }\end{array}$ \\
\hline
\end{tabular}

(Sumber : Lampiran 4)

Dari hasil identifikasi faktor eksternal didapatkan beberapa hal yang menjadi peluang serta ancaman Rumah Kompos. Faktor-faktor kunci tersebut, adalah :

\section{Peluang}

a) Perkembangan Teknologi dan Inovasi Produk

Perkembangan Teknologi sangat membantu Rumah Kompos untuk dapat 
menghasilkan pupuk kompos secara efisien dengan kualitas yang baik. Hal ini terkait dengan metode-metode maupun mesinmesin baru yang digunakan untuk membuat pupuk kompos secara optimal.

Rumah Kompos juga menerapkan inovasi dari hasil produk sehingga dinilai dapat bersaing dengan produk yang ada saat ini dipasaran. inovasi produk adalah inovasi yang digunakan dalam keseluruhan operasi perusahaan dimana sebuah produk baru diciptakan dan dipasarkan, termasuk inovasi disegala proses kegunaanya. Rumah Kompos saat ini telah memproduksi dua macam produk pupuk kompos dan pupuk cair EM 10 yang merupakan inovasi terbaru dari Rumah Kompos. Kedua jenis pupuk ini diharapkan bermanfaat bagi masyarakat dalam proses mempercepat penguraian sampah maupun sebagai pupuk pada tanaman.

b) Kebijakan Pemerintah Program "GO ORGANIK 2010"

Program GO ORGANIK 2010 merupakan program yang dicanangkan pemerintah untuk menunjang program ketahanan dan kemandirian di bidang pertanian. Dengan digulirkannya program pertanian tersebut, berdampak semakin banyaknya pelaku usaha yang turut serta berpartisipasi mensukseskan ketahanan dan kemandirian di bidang pertanian. Salah satunya adalah para pelaku usaha Pupuk Organik. Para pelaku pupuk organik bukan hanya berskala besar, tetapi juga skala rumah tangga. Dengan memanfaatkan limbah dan bahan organik di lingkungan maka akan menghasilkan nilai tambah ekonomis dan sosial budaya. Oleh karena salah satu hal tersebut Rumah kompos fokus dipengolahan sampah menjadi pupuk kompos.

c) Daya Beli Masyarakat terhadap Produk

Masyarakat pada umumnya sudah mulai tersadar akan bahayanya produk kimia. Karena dampak yang diakbibatkan sangat mengganggu bagi kesehatan. Oleh sebab itu tren masyarakat saat ini yang sudah gemar menggunakan produk organik. Hal tersebut dijadikan Rumah Kompos sebagai peluang untuk usaha. Melihat potensi ini Rumah Kompos ingin menangkap peluang yang ada dan berpartisipasi sebagai produsen pupuk organik untuk masyarakat khususnya Tanggerang Selatan.

\section{Ancaman}

a) Kenaikan TDL dan Kenaikan BBM

Kenaikan Tarif Dasar Listrik (TDL) pada kuartal II sebesar 4,3 persen yang bergulir sejak awal Mei 2013 dan kenaikan BBM pada 22 Juni 2013 telah berdampak pada dunia usaha khususnya biaya produksi dan pemasaran yang akan meningkat. Dengan kenaikan TDL dan kenaikan BBM tentunya akan menambah beban produksi Rumah Kompos. Daya listrik dibutuhkan untuk mengidupkan lampu, kulkas, mesin pengemas, mesin pembuat EM10. BBM digunakan untuk menghidupkan mesinmesin pencacah daun. Kenaikan BBM juga berpengaruh terhadap ongkos transportasi mendatangkan bahan baku maupun mendistibusikan produk dari Rumah Kompos ke konsumen.

b) Persaingan Harga Produk

Harga yang ditetapkan Rumah Kompos pada dua produknya merupakan harga standar di pasaran untuk perusahaan 
kecil maupun UKM akan tetapi bagi perusahaan besar yang produksinya secara besar-besaran mereka biasanya mematok harga dibawah harga standard, karena mereka mempunyai modal yang kuat dan besar sehingga perusahaan rela menekan keuntungan untuk memegang kendali pasar. Hal ini dapat menjadi ancaman bagi produk Rumah Kompos.

\section{c) Kenaikan Harga Bahan Baku}

Pupuk kompos yang proses pembuatanya terdiri dari dua bahan yaitu bahan utama dan campuran. Untuk bahan utama berupa serasah rumput dan dedaunan yang didapat dari lingkungan kampus memang tidak dipengaruhi oleh kenaikan harga, akan tetapi untuk bahan campuran seperti kotoran sapi, sekam bakar yang dibeli dari luar, kenaikan harga pada bahan campuran inilah yang sangat mempengaruhi biaya produksi pupuk kompos. Kenaikan ini juga dipengaruhi dengan kenaikan harga bbm karena untuk mendatangkan kotoran sapi dan sekam dari luar Tangerang Selatan memerlukan alat transportasi yang dalam operasionalnya membutukan BBM.

d) Produk Subtitusi

Kompos adalah pupuk organik yang berasal dari sampah rumah tangga, sampah tanaman, sampah pasar dan lain-lain dan dibuat melalui proses pengomposan. Seperti yang kita ketahui bahwa zat-zat yang terdapat pada pupuk kompos tidak dapat dengan cepat dan mudah diserap oleh tanaman, hal ini karena proses penguraian zat dari pupuk kompos ke tanaman membutuhhkan proses yang agak lama dibandingkan dengan pupuk kimia yang efeknya langsung cepat terhadap tanaman, oleh karenanya bagi masyarakat maupun petani yang awam lebih senang menggunakan pupuk kimia daripada pupuk oraganik karena hasilnya lebih cepat didapatkan.

\section{e) Perubahan Cuaca dan Iklim}

Perubahan cuaca dan iklim sangat mengancam bagi produksi pupuk kompos karena pada tahap penjemuran kotoran sapi membutuhkan bantuan sinar matahari agar kotoran sapi bisa kering dan memudahkan untuk pencampuran dengan bahan lainnya. Untuk suhu dan kelembaban juga sangat mempengaruhi proses pengomposan, semakin tinggi suhu pengomposan akan berjalan baik akan tetapi jika suhu terlalu rendah proses fermentasi kompos akan terhambat bahkan bisa menjadi gagal. Oleh karenanya dalam proses produksi pupuk kompos cuaca dan iklim sangat mempengaruhi keberhasilannya.

\section{Identifikasi Posisi Rumah Kompos UIN Jakarta}

\section{Matriks Internal Factor Evaluation (IFE)}

Setelah mengetahui faktor-faktor strategi internal rumah kompos yang menjadi kekuatan dan kelemahan terhadap kegiatan pengembangannya, maka selanjutnya dilakukan pemberian rating dan bobot terhadap masing-masing faktor. Pemberian rating dan bobot ini berfungsi untuk menyusun Matriks Internal Faktor Evaluation (IFE) dan mengetahui faktorfaktor strategis internal rumah kompos berkaitan dengan kekuatan dan kelemahan yang dianggap penting. Nilai skor yang diperoleh dapat memberi gambaran tentang faktor strategis yang menjadi kekuatan utama dan kelemahan utama bagi rumah 
kompos. Matriks IFE dapat dilihat pada Tabel 3 di bawah ini.

Tabel 50. Hasil analisis Matriks Internal Factor Evaluation (IFE)

\begin{tabular}{|l|c|c|c|}
\hline & $\begin{array}{c}\text { RATAAN } \\
\text { RATING }\end{array}$ & $\begin{array}{c}\text { RATAAN } \\
\text { BOBOT }\end{array}$ & SKOR \\
\hline KEKUATAN & & & \\
\hline Visi dan Misi Perusahaan & 4 & 0.10 & 0.40 \\
\hline Kualitas Produk & 4 & 0.06 & 0.24 \\
\hline Harga Produk & 4 & 0.08 & 0.32 \\
\hline Lokasi Perusahaan & 4 & 0.10 & 0.40 \\
\hline \multicolumn{1}{|c|}{ Fasilitas Produksi dan Operasi } & 4 & 0.07 & 0.28 \\
\hline Lahan yang Luas & 3.33 & 0.11 & 0.37 \\
\hline Bahan Baku yang Melimpah & 4 & 0.08 & 0.32 \\
\hline KELEMAHAN & & & \\
\hline $\begin{array}{l}\text { Ketersediaan Sumber daya } \\
\text { Manusia }\end{array}$ & 1 & 0.07 & 0.07 \\
\hline $\begin{array}{l}\text { Spesifikasi Pekerjaan } \\
\text { Sumber daya Manusia }\end{array}$ & 1.67 & 0.08 & 0.13 \\
\hline Pembukuan Keuangan & 1.33 & 0.09 & 0.12 \\
\hline Pemasaran Produk & 1 & 0.08 & 0.08 \\
\hline Kapasitas Produksi & 1 & 0.08 & 0.08 \\
\hline TOTAL & & 1 & 2.81 \\
\hline
\end{tabular}

Berdasarkan hasil perhitungan matriks IFE yang dilakukan pada Rumah Kompos yang menjadi kekuatan utamanya adalah visi-misi dan lokasi perusahaan yang dimiliki oleh Rumah Kompos dengan total nilai 0.40. Sedangkan yang menjadi kekuatan kecil bagi Rumah Kompos adalah kualitas produk dengan total nilai 0.24 , ini dikarenakan masih belum berjalannya proses kualiti kontrol produk. Dari data yang didapat, diketahui bahwa yang menjadi kelemahan utama bagi Rumah Kompos adalah spesifikasi pekerjaan tiap sumber daya manusia dengan total nilai 0.13. Sedangkan yang menjadi kelemahan kecil adalah kapasitas produksi dan pemasaran produk rumah kompos dengan total nilai 0.08. Secara keseluruhan berdasarkan Tabel 10 di atas, dapat diketahui bahwa total skor faktorfaktor strategis internal rumah kompos adalah 2.81. Hal ini menunjukkan bahwa rumah kompos berada pada kondisi di atas ratarata (2.50) yang artinya posisi rumah kompos mampu memanfaatkan kekuatankekuatan yang dimiliki berdasarkan hasil penilaian responden untuk mengatasi kelemahan perusahaan secara optimal.

\section{Matriks External Factor Evaluation (EFE)}

Setelah mengetahui faktor-faktor strategi eksternal Rumah Kompos yang menjadi peluang dan ancaman terhadap kegiatan pengembangannya, maka selanjutnya dilakukan pemberian rating dan bobot terhadap masing-masing faktor. 
Tabel 4. Hasil analisis Matriks External Factor Evaluation (EFE)

\begin{tabular}{|l|c|c|c|}
\hline & $\begin{array}{c}\text { RATAAN } \\
\text { RATING }\end{array}$ & $\begin{array}{c}\text { RATAAN } \\
\text { BOBOT }\end{array}$ & SKOR \\
\hline PELUANG & & & \\
\hline $\begin{array}{l}\text { Perkembangan Teknologi dan } \\
\text { Inovasi Produk }\end{array}$ & 2.67 & 0.09 & 0.24 \\
\hline $\begin{array}{l}\text { Kebijakan Pemerintah Program } \\
\text { "GO ORGANIK } \\
\text { 2010” }\end{array}$ & 3.33 & 0.09 & 0.30 \\
\hline $\begin{array}{c}\text { Daya Beli Masyarakat } \\
\text { terhadap Produk }\end{array}$ & 2.00 & 0.08 & 0.16 \\
\hline ANCAMAN TDL dan & 2.67 & 0.14 & 0.37 \\
\hline $\begin{array}{l}\text { Kenaikan Henaikan BBM } \\
\text { Persaingan Harga Produk }\end{array}$ & 2.00 & 0.13 & 0.26 \\
\hline $\begin{array}{l}\text { Kenaikan Bahan } \\
\text { Baku }\end{array}$ & 2.67 & 0.14 & 0.37 \\
\hline Produk Subtitusi & 2.67 & 0.14 & 0.37 \\
\hline Perubahan Cuaca dan Iklim & 2.33 & 0.19 & 0.44 \\
\hline TOTAL & & 1 & 2.52 \\
\hline
\end{tabular}

Pemberian rating dan bobot ini berfungsi untuk menyusun Matriks External Faktor Evaluation (EFE) dan mengetahui faktor-faktor strategis eksternal Rumah Kompos berkaitan dengan peluang dan ancaman yang di anggap penting. Nilai skor yang diperoleh dapat memberi gambaran tentang faktor strategis yang menjadi peluang utama dan ancaman utama bagi rumah kompos. Berdasarkan faktorfaktor strategis eksternal yang telah di analisa kemudian disusun matriks EFE dengan memberikan rating dan perhitungan bobot, sehingga dihasilkan skor.

Berdasarkan perhitungan matriks EFE yang dilakukan pada rumah kompos dapat diketahui peluang yang sangat berpengaruh terhadap pengembangan Rumah Kompos adalah kebijakan pemerintah program Go Organik 2010 dengan total nilai 0.30. Sedangkan peluang yang sangat kecil pengaruhnya adalah daya beli masyarakat dengan total nilai 0.16. Dari data yang didapat pula, diketahui bahwa ancaman yang berpengaruh pada rumah kompos adalah perubahan cuaca dan iklim dengan total nilai 0.44. Sedangkan ancaman kecil bagi rumah kompos adalah persaingan harga produk dengan total nilai 0.26 .

Secara keseluruhan berdasarkan Tabel 3 di atas, dapat diketahui bahwa total skor faktor-faktor strategis eksternal rumah kompos adalah 2.52. Hal ini menunjukkan bahwa rumah kompos berada pada kondisi di atas rata-rata (2.50) yang artinya posisi rumah kompos mampu memanfaatkan peluang-peluang yang dimiliki berdasarkan hasil penilaian responden untuk mengurangi ancaman yang dihadapi. 


\section{Matriks Internal-Eksternal (IE)}

Setelah diperoleh skor dari matriks IFE yang memberikan gambaran tentang kekuatan dan kelemahan yang dimiliki dan matriks EFE yang menggambarkan tentang kondisi peluang dan ancaman yang dihadapi rumah kompos, selanjutny perusahaan dapat melakukan tahap pemanduan antara matriks IFE dan Matriks EFE. Berdasarkan hasil skor yang diperoleh dari Matriks IFE dan Matriks EFE, maka diketahui posisi rumah kompos pada Matriks Internal-Eksternal (IE). Matriks IE dapat dilihat pada Gambar 1 berikut:

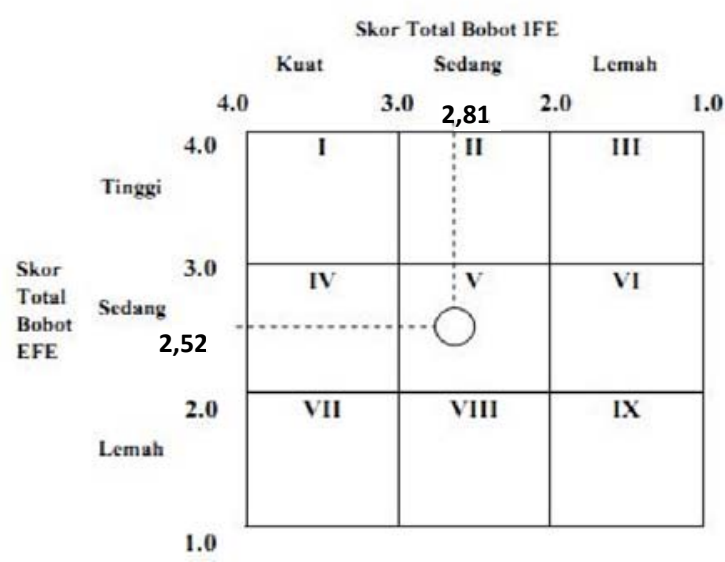

Gambar 11. Hasil analisis Matriks I-E (Internal dan Eksternal)

Matriks I-E digunakan untuk mengetahui posisi perusahaan saat ini dengan berdasarkan dari total skor bobot matriks IFE dan matriks EFE. Besarnya total skor bobot IFE sebesar 2.81 sedangkan total bobot skor EFE sebesar 2.52.

Berdasarkan total skor bobot yang diperoleh dari matriks IFE dan matriks EFE, menenpatkan rumah kompos berada pada kuadran $\mathrm{V}$, artinya strategi yang dapat dilaksanakan pada sel $\mathrm{V}$ adalah mempertahankan dan menjaga (Hold and Maintain). Strategi yang umum digunakan pada posisi ini adalah melakukan penetrasi pasar dan pengembangan produk.

\section{Perumusan Alternatif Strategi Rumah Kompos UIN Jakarta}

\section{Matriks Strenghts Weakness Oppourtunities Threats (SWOT)}

Matriks SWOT memberikan gambaran dengan jelas tentang faktorfaktor yang menjadi kekuatan dan kelemahan serta peluang dan ancaman yang dimiliki rumah kompos. Matriks SWOT berisi strategi kombinasi S-O (StrengthOpportunities), S-T (StrenghtThreats), W-O (Weakness-Opportunities), dan W-T (Weakness- Threats).

Analisis ini menggunakan data yang telah diperoleh dari matriks IFE dan matriks EFE. Matriks SWOT mengenai kondisi di rumah kompos dapat di lihat melalui Tabel 4 yang ada di bawah ini: 
Tabel 51. Hasil analisis Matriks Strenghts-Weakness-Oppourtunities-Threats (SWOT)

\begin{tabular}{|c|c|c|}
\hline IFE & Kekuatan (Strenghts) & Kelemahan (Weakness) \\
\hline EFE & $\begin{array}{l}\text { 1.Visi dan Misi } \\
\text { Perusahaan } \\
\text { 2.Kualitas Produk } \\
\text { 3.Harga Produk } \\
\text { 4.Lokasi Perusahaan } \\
\text { 5.Fasilitas Produksi dan } \\
\text { Operasi } \\
\text { 6.Lahan yang Luas } \\
\text { 7.Bahan Baku } \\
\text { yang } \\
\text { Melimpah }\end{array}$ & $\begin{array}{l}\text { 1.Ketersediaan Sumber daya Manusia } \\
\text { 2.Spesifikasi Pekerjaan } \\
\text { Tiap Sumber daya Manusia } \\
\text { 3.Pembukuan Keuangan } \\
\text { 4.Pemasaran Produk } \\
\text { 5.Kapasitas Produksi }\end{array}$ \\
\hline $\begin{array}{l}\text { Peluang } \\
\text { (Oportunities) }\end{array}$ & Strategi S-O & Strategi W-O \\
\hline $\begin{array}{l}\text { 1.Perkembangan } \\
\text { Teknologi dan } \\
\text { Inovasi Produk } \\
\text { 2.Kebijakan } \\
\text { Pemerintah } \\
\text { Program } \\
\text { "GO ORGANIK } \\
\text { 2010" } \\
\text { 3.Daya Beli } \\
\text { Masyarakat } \\
\text { terhadap } \\
\text { Produk }\end{array}$ & $\begin{array}{l}\text { 1.Peningkatan Kualiatas } \\
\text { dan Kapasitas Produksi } \\
\text { Perusahaan } \\
(\mathrm{S} 1, \mathrm{~S} 2, \mathrm{~S} 5, \mathrm{~S} 6, \mathrm{~S} 7, \mathrm{O} 1) \\
\text { 2.Pengembangan Pasar } \\
(\mathrm{S} 3, \mathrm{~S} 4, \mathrm{O} 2, \mathrm{O} 3)\end{array}$ & $\begin{array}{l}\text { 1.Merekrut tenaga kerja } \\
\text { baru(W1,W2,W3,W4,W5,O1) 2.Menata ulang } \\
\text { struktur organisasi dan pembagian tugas sesuai } \\
\text { dengan SOP } \\
(\mathrm{W} 2, \mathrm{~W} 3, \mathrm{~W} 5, \mathrm{O} 2,03)\end{array}$ \\
\hline Ancaman (Threats) & Strategi S-T & Strategi W-T \\
\hline
\end{tabular}




\begin{tabular}{|l|l|l|}
\hline \begin{tabular}{l} 
1.Kenaikan TDL \\
dan Kenaikan BBM \\
2.Persaingan \\
\multicolumn{1}{|c|}{ Harga } \\
Produk
\end{tabular} & $\begin{array}{l}\text { 1.Kerja sama dengan mitra } \\
\text { dan pemasok } \\
\text { (S1,S2,S3,S4,S5,S6,S7, } \\
\text { 3.Kenaikan } \\
\begin{array}{l}\text { Harga } \\
\text { T1,T2,T3,T4,T5) }\end{array}\end{array}$ & $\begin{array}{l}\text { 1.Memperbaiki sitem manajemen guna menahan } \\
\text { laju persaingan dari luar. } \\
\text { (W1,W2,W3,W4,W5, } \\
\text { Bahan Baku }\end{array}$ \\
$\begin{array}{l}\text { 4.Produk Subtitusi } \\
\text { 5.Perubahan } \\
\text { Cuaca }\end{array}$ & \\
dan Iklim & \\
\hline
\end{tabular}

(Sumber : Data Primer Diolah)

\section{Alternatif Strategi Pengembangan Rumah Kompos}

Alternatif strategi pengembangan Rumah Kompos diperoleh melalui matriks SWOT yang menggambarkan dengan jelas faktor-faktor strategis yang menjadi kekuatan dan kelemahan serta yang menjadi peluang dan ancaman bagi Rumah Kompos. Formulasi strategi ini dilakukan dengan menggunakan alat analisis SWOT. Strategi yang dihasilkan berupa kombinasi $S-O$ (StrengthOpportunities), $S-T$ (StrenghtThreats), W-O (Weakness-Opportunities), dan W-T (Weakness- Threats).

\section{Strategi S-O}

Strategi S-O merupakan strategi yang menggunakan kekuatan dengan memanfaatkan peluang yang ada. Strategi ini dibuat untuk mengoptimalkan kekuatan dari Rumah Kompos dengan merespon peluang yang ada.

Alternatif strategi S-O antara lain:

$\begin{array}{lll}\text { 1) Peningkatan } & \text { Kualitas dan } \\ \text { Kapasitas } & \text { Produksi }\end{array}$

\section{Rumah Kompos}

(S1,S2,S5,S6,S7,O1)

Rumah Kompos melakukan peningkatan kualitas dengan cara melakukan kualiti control pada setiap kali produksi dan kapasitas produksi dapat ditingkatkan dengan menambah alat untuk produksi khususnya produksi pada saat pencacahan serasah daun. Dalam peningkatan kapasitas produksi, pihak Rumah Kompos juga harus menambah jumlah pemasok bahan baku sehingga proses produksi dapat berjalan dengan baik dan kapasitas produksi dapat lebih ditingkatkan.

2) Pengembangan

Pasar (S3,S4,O2,O3)

Pengembangan pasar dapat dilakukan dengan mencoba menjalin kerja sama dengan toko-toko pertanian disekitar Tangerang Selatan dan juga mempromosikan produk dengan bantuan media internet. 


\section{Strategi S-T}

Strategi S-T merupakan strategi yang menggunakan kekuatan untuk meminimalisasi ancaman. Strategi S-T dibuat untuk meminimalkan ancaman yang dihadapi Rumah Kompos dengan memaksimalkan kekuatan yang ada. Alternatif strategi S-T antara lain:

1) Kerja sama dengan mitra dan pemasok (S1,S2,S3,S4,S5,S6,S7 ,T1,T2,T3,T4,T5).

Kegiatan pengembangan Rumah Kompos dalam semua produk yang ada tidak terlepas dari peran semua pihak, oleh karena itu Rumah Kompos mengadakan kerja sama dengan pihak-pihak terkait. Kerja sama dapat dilakukan dengan cara bermitra dengan instansi, pemasok, distributor, maupun konsumen.

\section{Strategi W-O}

Strategi W-O merupakan strategi dengan memperkecil kelemahan untuk memanfaatkan peluang. Startegi ini dibuat untuk meminimalisir kelemahan yang ada pada Rumah Kompos dengan memanfaatkan peluang yang dimiliki. Alternatif strategi W-O antara lain:

1) Merekrut tenaga kerja baru (W1,W2,W3,W4,W5,O1).

Tenaga kerja di rumah kompos masih sangat terbatas jumlahnya, dapat dilihat dari struktur organisasi yang ada, orang-orang yang berkecimpung di rumah kompos hanya sisa 4 orang. Hal itulah yang membuat kegiatan operasional rumah kompos menjadi terganggu dan belum bisa optimal.

2) Menata ulang struktur organisasi dan pembagian tugas sesuai dengan SOP (W2,W3,W5,O2,03).
Struktur organisasi Rumah Kompos saat ini masih sangat sederhana, dan mengakibatkan pembagian tugas setiap pegawainya masih belum terorganisir. Perusahaan yang terorganisir membuat perusahaan dapat dengan mudah mencapai tujuan perusahaan, begitu juga sebaliknya apabila perusahaan yang tidak terorganisir membuat perusahaan akan sulit mencapai tujuannya.

\section{Strategi W-T}

$\mathrm{S}$ trategi W-T merupakan strategi dengan meminimalkan kelemahan dan mengantisipasi ancaman. Strategi ini dibuat unutk meminimalisir kelemahan dan ancaman yang dihadapi oleh Rumah Kompos. Alternatif strategi W-T yaitu:

1) Memperbaiki sitem manajemen guna menahan laju persaingan dari luar. (W1, W2, W3, T2, T3)

\section{Manajemen Rumah Kompos saat ini} kurang baik, sebaiknya perlu dikembangkan lagi agar menjadi lebih baik. Dalam manajemen perlu diperhatikan bahwa fungsi-fungsi manajemen terdiri dari, pertama fungsi perencanaan, yang mencakup proses memutuskan sasaran, memutuskan suatu strategi untuk mencapai sasaran tersebut, dan menyusun rencana guna memadukan dan mengkoordinasi sejumlah kegiatan. Kedua fungsi pengorganisasian, yang mencakup proses penentu tugas apa yang harus dikerjakan, siapa yang harus mengerjakannya, bagaimana cara mengelompokkan tugastugas itu, siapa melapor kepada siapa, dan pada tingkatan apa keputusan harus diambil. Ketiga fungsi kepemimpinan, yang memotivasi bawahannya, mempengaruhi individu atau tim sewaktu mereka bekerja, 
memilih saluran komunikasi yang paling efektif, atau menyelesaikan masalah prilaku karyawan dengan cara apapun. Keempat, fungsi pengendalian, yang mengevaluasi untuk mengetahui apakah segala sesuatunya berjalan sesuai rencana, untuk menjamin agar segala sesuatunya berjalan sebagai mana mestinya. Hal ini dilakukan untuk mengoptimalkan kinerja manajemen agar menjadi lebih baik serta untuk mencapai tujuan yang telah disepakati bersama.

\section{Penentuan Prioritas Strategi Rumah Kompos UIN Jakarta}

Berdasarkan hasil yang didapat dari matriks IE dan matriks SWOT diperoleh beberapa alternatif strategi yang dapat dijalankan oleh Rumah Kompos. Alternatif strategi yang dibuat ini tidak dapat dijalankan secara bersamaan, oleh karena itu perlu adanya penentuan prioritas strategi untuk mengetahui strategi mana yang harus didahulukan. Alat yang digunakan dalam menentukan prioritas strategi yang akan dijalankan yaitu QSPM (Quantitative Strategic Planning Matriks).

Alternatif strategi yang diperoleh dari matrik SWOT antara lain:
1. Peningkatan Kualitas dan Kapasitas Produksi Perusahaan

2. Pengembangan Pasar

3. Merekrut tenaga kerja baru

4. Menata ulang struktur organisasi dan pembagian tugas sesuai dengan SOP

5. Kerja sama dengan mitra dan pemasok

6. Memperbaiki sistem manajemen guna menahan laju persaingan dari luar Berdasarkan perhitungan dari QSPM melalui evaluasi strategi dari matriks SWOT maka diperoleh penentuan prioritas strategi seperti pada Tabel 5 berikut.

Berdasarkan Tabel 5 di atas menunjukkan bahwa alternatif strategi yang menjadi prioritas utama untuk dijalankan oleh Rumah Kompos adalah Strategi 1 yaitu peningkatan kualitas dan kapasitas produksi Rumah Kompos dengan total skor 6.986 . peningkatan kualiatas dan kapasitas produksi dapat dilakukan dengan memanfaatkan bahan baku yang sudah ada ditambah dengan fasilitas produksi dan operasi yang cukup lengkap.

Tabel 52. Prioritas Strategi Pengembangan Rumah Kompos UIN Jakarta

\begin{tabular}{|c|l|c|}
\hline NO. & \multicolumn{1}{|c|}{ PRIORITAS STRATEGI } & $\begin{array}{c}\text { TOTAL } \\
\text { SKOR }\end{array}$ \\
\hline 1. & Peningkatan Kualitas dan Kapasitas Produksi Rumah Kompos & 6.986 \\
\hline 2. & Pengembangan Pasar & 6.913 \\
\hline 3. & Kerja sama dengan mitra dan pemasok & 6.020 \\
\hline 4. & Merekrut tenaga kerja baru laju & 4.293 \\
\hline 5. & $\begin{array}{l}\text { Memperbaiki sitem manajemen guna menahan } \\
\text { persaingan dari luar }\end{array}$ & 4.740 \\
\hline 6. & $\begin{array}{l}\text { Menata ulang struktur organisasi dan pembagian tugas sesuai } \\
\text { dengan SOP }\end{array}$ \\
\hline
\end{tabular}


Strategi 2 yaitu pengembangan pasar dapat dilakukan dengan membuka link pemasaran ke daerah-daerah baru baik itu perkotaan maupun pelosok pedesaan dan memanfaatkan teknologi internet untuk mengenalkan dan memasarkan produk Rumah Kompos ke masyarakat umum. Strategi 3 yaitu kerja sama dengan mitra dan pemasok dapat dilakukan dengan cara menjalin kemitraan baik dengan instansi maupun individu seperti toko-toko penjual alat-alat pertanian dan menjaga hubungan dengan pemasok bahan baku agar terciptanya kerja sama yang berkesinambungan. Strategi 4 yaitu merekrut tenaga kerja baru dapat dilakukan dengan meminta beberapa karyawan Kampus UIN Jakarta untuk menjadi karyawan Rumah Kompos atau dengan melakukan kerjasama dengan mahasiswa untuk dapat ikut berpartisipasi dan membantu dalam operasional Rumah Kompos UIN Jakarta. Strategi 5 yaitu memperbaiki sistem manajemen guna menahan laju persaingan dari luar dapat dilakukan dengan cara memberikan pelatihan kepada pengurus Rumah Kompos agar sumberdaya manusia yang ada menjadi lebih baik dan siap bersaing. Strategi 6 yaitu menata ulang struktur organisasi dan pembagian tugas sesuai SOP dapat dilakukan dengan cara merubah struktur organisasi yang ada menjadi lebih lengkap dan meberikan masing-masing pengurus spesifikasi pekerjaan agar tidak ada lagi yang mempunyai tanggung jawab lebih dari satu. Serta memberlakukan SOP disetiap proses produksi agar proses produksi menjadi lebih efektif dan efisien.

\section{KESIMPULAN DAN SARAN}

\section{Kesimpulan}

1. Identifikasi faktor strategis internal pada Rumah Kompos yang menjadi kekuatan utama adalah visi \& misi perusahaan dan lokasi perusahaan dengan skor bobot 0.40. Sedangkan faktor strategis internal yang menjadi kelemahan utama adalah spesifikasi pekerjaan tiap sumber daya manusia dengan skor bobot 0.13 .

Identifikasi faktor strategis eksternal pada Rumah Kompos yang menjadi peluang utama adalah kebijakan pemerintah program GO ORGANIK 2010 dengan skor bobot 0.30 . Sedangkan faktor strategis eksternal yang menjadi ancaman bagi Rumah Kompos adalah perubahan cuaca dan iklim dengan skor bobot 0.44 .

2. Berdasarkan total skor bobot yang diperoleh dari matriks IFE dan matriks EFE sebesar 2.81 dan 2.52, menenpatkan rumah kompos berada pada kuadran $\mathrm{V}$, artinya strategi yang dapat dilaksanakan pada sel $\mathrm{V}$ adalah mempertahankan dan menjaga (Hold and Maintain). Strategi yang umum digunakan pada posisi ini adalah melakukan penetrasi pasar dan pengembangan produk.

3. Alternatif strategi dalam pengembangan Rumah Kompos dengan menggunakan matriks SWOT. Strategi (SO) yaitu Peningkatan Kualitas Dan Kapasitas Produksi Rumah Kompos, Pengembangan Pasar. Strategi (ST) yaitu,Kerja Sama Dengan Mitra Dan Pemasok. Strategi (WO) yaitu, Merekrut Tenaga Kerja Baru, Menata Ulang Struktur Organisasi Dan 
Pembagian Tugas Sesuai Dengan Sop.

Strategi (WT) yaitu, Memperbaiki Sitem Manajemen Guna Menahan Laju Persaingan Dari Luar.

Prioritas utama dari QSPM yang dapat dijalankan Rumah Kompos adalah Peningkatan Kualitas Dan Kapasitas Produksi dengan total skor 6.986 . Kemudian urutan prioritas selanjutnya adalah Pengembangan Pasar, Kerjasama Dengan Mitra Dan Pemasok, Merekrut Tenaga Kerja Baru, Memperbaiki Sistem Manajemen Guna Menahan Laju Persaingan Dari Luar, Dan Menata Ulang Struktur Organisasi Dan Pembagian Tugas Sesuai Dengan Sop.

\section{Saran}

Berdasarkan penelitian yang dilakukan oleh penulis, maka dapat dikemukakan beberapa saran yang dapat diajukan kepada Rumah Kompos antara lain:

1. Meningkatkan kualitas dan kapasitas produk dengan memanfaat potensi yang dimiliki baik itu bahan baku maupun peralatan penunjang lainnya agar produk Rumah Kompos dapat terjamin kualitasnya dan bersaing dengan produk lainya.

2. Memperbaiki sistem majemen dengan salah satunya menata ulang struktur organisasi dan pemberian tugas kepada tiap sumber daya manusia.

3. Semoga perusahaan dapat memanfaat hasil penelitian ini sebagai bahan pertimbangan untuk pengambilan keputusan.

\section{DAFTAR PUSTAKA}

“Harga BBM Resmi Naik, Bensin Rp 6.500 per Liter." Tempo, 21 Juni 2013. Artikel diakses pada Tanggal 5 November 2013 dari http://www.tempo.co/read/news/ 2013/06/21/090490286/HargaBBMResmi-Naik-Bensin-Rp6500-per-Liter.

"Kaleidoskop Dinas Kebersihan DKI Jakarta 2010." Artikel diakses pada tanggal 22 Januari 2014 dari

http://persampahan.wordpress.co m/2011/01/03/kaleidoskopdinaskebersihan-dki-jakarta2010/.

"Memanfaatkan Sampah Organik Dan Kotoran Hewan Jadi Pupuk Kompos” Ide Bisnis, 4 Mei 2012. Artikel dikases pada tanggal 18 November 2013 dari http://idebisnis.wirausahanews.com/2012 $\underline{0504 / 275-}$ memanfaatkansampah-organikdan-jotoran-hewan-jadi-pupukkompos.html

David, Fred R. Strategic Management, Edisi Ke-10. Jakarta: PT. Prenhallindo, 2008.

David, Fred R. Strategic Management, Edisi Ke-10. Jakarta: Salemba Empat, 2006.

Hariadi, Bambang. Strategi Manajemen Strategi Memenangkan Perang Bisnis. Malang: Bayu Media, 2005.

Januargo, Puguh Wahyu. "Strategi Pengembangan Bisnis Pupuk Hayati Biofertilizer Pada Balai 


\section{Teknologi Perkebunan Indonesia.” Skripsi S1}

Fakultas Sains dan Teknologi, Universitas Islam Negeri Syarif Hidayatullah Jakarta, 2011.

Kotler, Philip. Manajemen Pemasaran. Jakarta: PT. Prenhallindo, 2002.

Lingga, Pinus dan Marsono. Petunjuk Penggunaan Pupuk. Jakarta: Penebar Swadaya, 2003.

Malik, Syaiful. "Strategi Pengembangan Agrowisata Kandang Jurang Doang." Skripsi S1 Fakultas Sains dan Teknologi, Universitas Islam Negeri Syarif Hidayatullah Jakarta, 2010.

Pearce dan Robinson. Manajemen Strategik, Jilid Satu. Jakarta: Binarupa Aksara, 1997.

Peraturan Menteri Pertanian Nomor 02/pert/Hk.060/2/2006.

Peraturan Pemerintah Nomor 81 Tahun 2012

Profil Rumah Kompos UIN Jakarta 2013

Rangkuti, Freddy. Analisis SWOT Teknik Membedah Kasus Bisnis. Jakarta: PT. Gramedia Pustaka Utama, 2006.

Rangkuti, Freddy. Riset Pemasaran. Jakarta: PT. Gramedia Pustaka Utama, 2006.

Reza, Ahmad. "APBD Bukan Untuk Anggaran Ilegal: Kasus Pengelolaan Sampah Tangsel" Diakses pada tanggal 10 Desember 2013 dari http://soranaza.blogspot.com/20 $\underline{11 / 10 / a p b d-b u k a n-u n t u k-}$ anggaran-ilegalkasus.html

Sa' diyah, Halimatus. "Warga Jakarta Produksi Sampah 6.500 Ton per Hari" Diakses pada tanggal 21 Februari 2013 dari

http://www.republika.co.id/berit a/nasional/jabodetabeknasional/13/02/21/mikcauwarga-jakarta-produksi-sampah6500-ton-perhari

Saputri, Friskalia Ratih. "Strategi Pengembangan Bisnis Tanamana Hias PT. Istana Alam Dewi Tara." Skripsi S1 Fakultas Ekonomi, Institut Pertanian Bogor, 2012.

Tjiptono, Fandy. Strategi Pemasaran (Edisi Kedua). Yogyakarta: Andi, 2002.

Tripomo, Tedjo dan Udan. Manajemen Strategi. Bandung: Rekayasa Sains, 2002.

Umar, Husein. Strategic Management in Action. Jakarta: Gramedia Pustaka Utama, 2001.

Undang-Undang Nomor 18 tahun 2008 tentang Pengelolaan Sampah. 


\section{Lampiran}

\section{Baner Rumah Kompos UIN Jakarta}

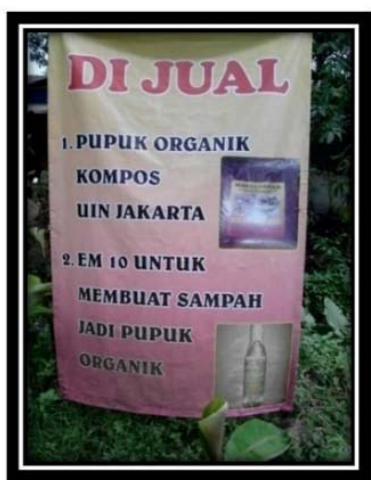

Pupuk Cair EM10

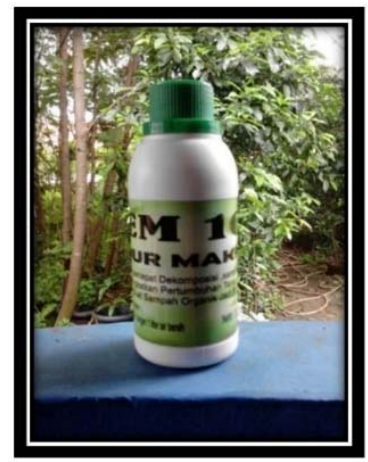

Pupuk Kompos ukuran 4kg

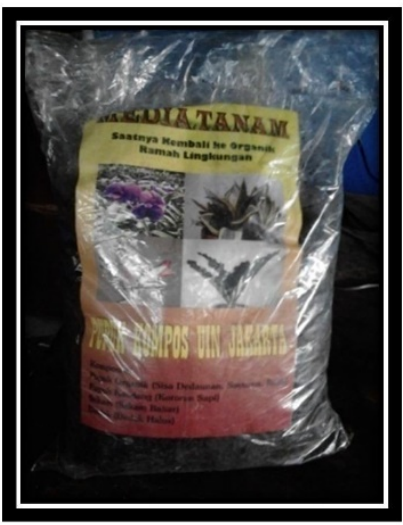

Pupuk Kompos ukuran $1 \mathrm{~kg}$

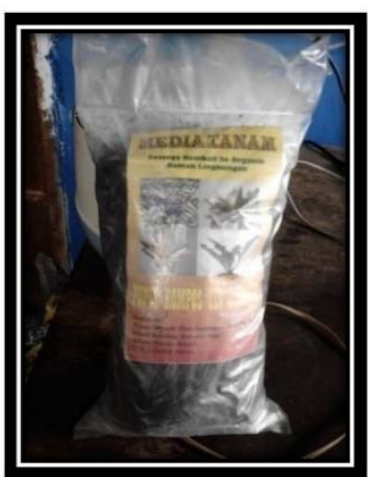

Stand Pameran

Rumah Kompos UIN Jakarta

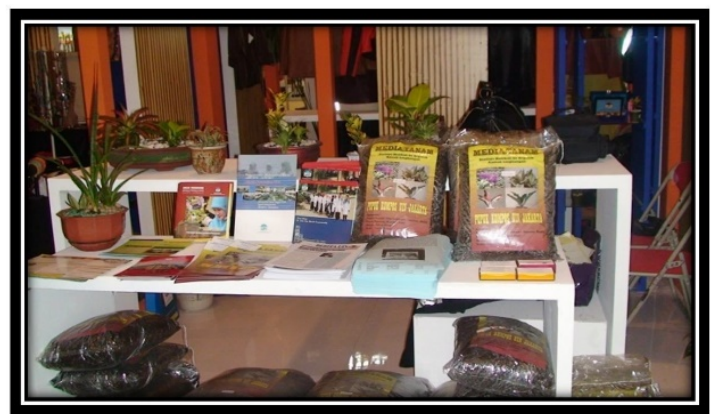

Pupuk Kompos ukuran 15kg

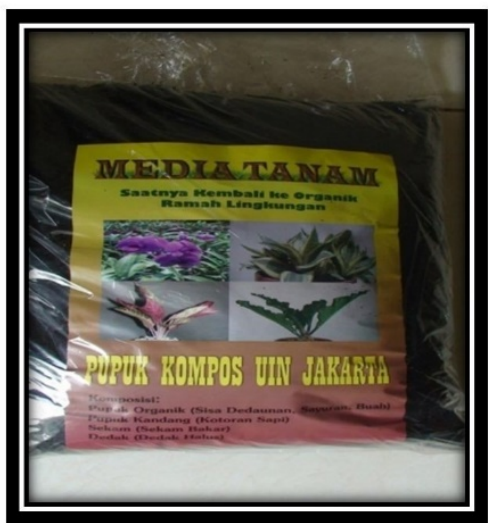

* Dosen Prodi Agribisnis FST UIN Syarif Hidayatullah Jakarta (Email:

elpawati@uinjkt.ac.id) 